\title{
A Tale of Two Women: Edith Lucas, Mary Ashworth, and the Changing Nature of Educational Policy in British Columbia, 1937-1977 ${ }^{1}$
}

\author{
Helen Raptis
}

Both Edith Lucas and Mary Ashworth were instrumental in the lives of minority learners in British Columbia between 1937 and 1988. Although their goals were similar, their professional experiences could not have been more different. Unbridled by the dictates of elected politicians from 1937 to 1963, Lucas provided teachers and students with the necessary resources and services to meet their educational needs directly. Conversely, from 1968 until the late 1970 s, Ashworth spent as much of her time lobbying elected officials for adequate resources as she did working with English-as-a-second-language teachers. The professional lives of Edith Lucas and Mary Ashworth illustrate the profound shifts in educational governance and social thought - and their aftermath - that occurred in British Columbia, as elsewhere in North America, from the late 1960 s onward.

Edith Lucas et Mary Ashworth influèrent toutes les deux sur la vie des élèves issus des minorités de Colombie Britannique de 1937 à 1988. Bien que leurs objectifs étaient similaires, leurs expériences professionnelles n'auraient pu être plus différentes. Non assujettie aux volontés des politiciens élus durant les années 1937 à 1963, Lucas fournit aux maîtres et aux élèves les ressources et les services nécessaires pour satisfaire directement leurs besoins éducatifs. Inversement, de 1968 jusqu'à la fin de la décennie 1970, Ashworth passa autant de temps à solliciter des élus les ressources suffisantes qu'à œuvrer auprès des professeurs d'anglais langue seconde. La vie professionnelle d'Edith Lucas et de Mary Ashworth illustre les profonds changements de gestion en matière d'éducation et de pensée sociale ainsi que les conséquences qui s'ensuivirent en Colombie Britannique, comme ailleurs en Amérique du Nord, depuis la fin des années 1960.

British Columbia's first Public School Act of 1872 ensured that the provincial authorities in Victoria exercised "supreme authority" over all matters of public education - including credentialing and hiring teachers, as well as developing policy, curricula, examinations, and other

1 I wish to thank Thomas Fleming, Alison Prentice, and Harry Smaller for their helpful comments on an earlier version of this paper, presented at the 2004 annual meeting of the American Educational Research Association in San Diego, California. 
resources. Due largely to the logistic impossibility of having authorities in Victoria manage the day-to-day affairs of schools scattered across a sparsely populated, vast, and forbidding geographic terrain, the Act of 1872 permitted locally elected trustees to oversee the physical maintenance of school properties on the province's behalf. ${ }^{2}$ By 1972, however, British Columbia's tightly centralized and "imperial” school governance system had come unravelled. The educational civil service, once sole player in school affairs, was faced with reconciling its traditionally centralized governance with public demands for decentralization of power and greater local autonomy. As Thomas Fleming has noted, "public school history in British Columbia is essentially, a history in two parts." 3

The following narrative is also a tale in two parts. It describes the professional lives and contributions of Edith Lucas and Mary Ashworth - two women educators who were instrumental in promoting minority education during what Fleming describes as British Columbia's "imperial" (1872-1972) and "post-imperial” (post-1972) eras of public school governance. Although Lucas and Ashworth both devoted their professional lives to needs of minority learners in British Columbia, their professional experiences could not have been more different. From 1937 to 1963, Lucas operated unencumbered from within the provincial civil service and was generally successful in enabling minority learners to meet their educational needs. As a professor and lobbyist from 1968 to 1988, Ashworth remained blocked by the educational guard, advocating for minority learners from outside the system, but failing to achieve for her charges the kind of gains made by Lucas. Although the two women were separated by space and time, the great divide that distinguished Lucas's career from that of Ashworth is the profound shift in educational circumstance - and social thought - that occurred throughout North America during the late 1960s and early 1970s. In tracing the lives of these two women, this paper also chronicles the development of Englishas-a-second-language (ESL) schooling in British Columbia, a topic of research that, to date, has been neglected in historical scholarship.

Other jurisdictions around the world are also contending with the conflicting tensions that characterize a shift from centralized to decentralized governance. In "Education Policy Under Cultural Pluralism," the American sociologist Bruce Fuller contends that "vivid signs of contradiction, even chaos, now surface from within education policy circles with uncanny regularity." From his research findings, Fuller argues that the source of this tension lies in the majority culture's

2 F.H. Johnson, A History of Public Education in British Columbia (Vancouver: University of British Columbia, 1964), 88.

3 T. Fleming, "From Educational Government to the Government of Education: The Decline and Fall of the British Columbia Ministry of Education, 1972-1996," Historical Studies in Education 15 (Fall 2003): 210-36. 
postmodern "realization that diverse children grow up in legitimately different settings." ${ }^{4}$ As a result, cultural and organizational pluralism now challenges "old-style institution building" - dubbed by David Tyack as the "one best system" - in which state-controlled, centrally administered education was seen as the most effective means of offsetting societal inequalities and fostering nationhood.

Fuller further notes that the confusion surrounding educational policy is exacerbated by the fact that we have "little empirical work that traces these underlying political dynamics" and that illustrates the "intersection between local culture, multicultural politics, and decentralizing drifts in policy formulation." "Fuller's observation is not surprising, for the academic literature has long decried the lack of educational policy study both within education and in traditional policy fields such as political science. $^{7}$ Although, beginning in the late 1970s, historians began advocating for more historically grounded policy research, the historical scholarship on educational policy study has remained sparse. ${ }^{8}$ By

$4 \quad$ B. Fuller, “Education Policy Under Cultural Pluralism,” Educational Researcher, 32, (Dec. 2003): 15. Fuller is not alone in attributing culture as the basis of the shift in public education from classical liberalism to an as-yet-to-be-defined state of affairs. C.A. Bowers, for example, argued in 1987 that the liberal tenets of rational thought, individualism, and the value of progressive social change that guided early public schooling are fundamentally flawed, since they fail to account for the importance of social context in shaping people's underlying values and historical traditions. Bowers noted that peoples' needs to be recognized as social-cultural beings - rather than simply as autonomous, self-directed beings - have weakened the explanatory power of classical liberalism and necessitated a "post-liberal" theory of education. C.A. Bowers, Elements of a Post-Liberal Theory of Education (New York: Teachers College Press, 1987.)

5 D. Tyack, The One Best System: A History of American Urban Education (Cambridge, MA: Harvard University Press, 1974.)

6 Fuller, “Education Policy Under Cultural Pluralism,” 21-22.

7 See L. Downey, Policy Analysis in Education (Calgary: Detselig, 1988); A. Lieberman and M.W. McLaughlin, Policy Making in Education (Chicago: University of Chicago Press, 1982); L. Pal, Interests of State - The Politics of Language, Multiculturalism and Feminism (Montreal: McGill-Queen's University Press, 1993); B. Salter and T. Tapper, Education, Politics and the State (London, England: Grant McIntyre, 1981); J.T. Thompson, Policymaking in American Education: A Framework for Analysis (Englewood Cliffs, New Jersey: Prentice-Hall, Inc., 1976); and M. Vinovskis, History and Educational Policymaking (New Haven, CT: Yale University Press, 1999.)

8 Harold Silver notes that "policy analysts and policy makers have in a loose sense all become historians now, at least in the assumptions that they often make about the past." See Silver, "Policy Problems in Time," in Historical Perspectives on Educational Policy in Canada, ed. E.W. Ricker and B.A. Wood (Toronto: Canadian Scholars' Press, 1995), 32. For other contributions to this perspective, see E.W. Ricker, "Historians and the Study of Educational Policy: An Overview," in Historical Perspectives, 3-26; N. Stearns, "History and Public Policy," in Social Science and Public Policy: The Roles of Academic Disciplines in Policy Analysis, ed. G.J. McCall and G.H. Weber (New York: Associated Faculty Press, Inc., 1984), 91-128; D.R. Warren, “A Past for the Present," History, Education, and Public Policy, ed. Warren Berkeley (California: McCutchan Publishing Corporation, 1978), 1-20. Elizabeth Hansot and David Tyack offer three advantages of historical approaches to policy-making. The first of these is the 
chronicling the careers of Edith Lucas and Mary Ashworth during two distinct eras of educational governance and policy-making, this research seeks to address a historical gap in the educational policy literature.

\section{Edith Lucas: An Agent of the State}

Edith Ethel Lucas was an uncommonly accomplished educator for her time. Born in Ireland in 1904, Lucas and her family immigrated to Victoria, B.C. when she was a young girl. She attended North Ward Elementary School, characterized at that time by its diverse immigrant population, and graduated from Victoria High School at age 16. ${ }^{9}$ Her name still adorns the honour roll in the school's main entrance way and the commentary in her high school yearbook describes Lucas as an outstanding scholar, "inclined to studious habits," with a mind "set to learn and know." ${ }^{10}$ After graduating from high school, Lucas earned firstclass honours degrees in French and Latin from the University of British Columbia and received the Governor General's Gold Medal - the province's highest award for academic excellence. ${ }^{11}$

Lucas taught French at Powell River High School from 1925 until 1927, when she won the Nichol Scholarship for post-graduate studies. In three short years, Lucas completed her doctoral studies in French literature at the Sorbonne in Paris. With a $\mathrm{PhD}$ in hand, she returned to Canada and "stepped right in to the depression of the thirties," when it was virtually impossible to secure a teaching position. Looking back on her experiences several decades later, Lucas reported that she was "lucky" to have been granted the "only French position in the province at Chilliwack.” In 1931 she accepted a teaching post at Prince Rupert High School, and became principal in 1933, one of only a handful of women at the time to preside over a provincial secondary school.

During her time in Prince Rupert, she began what would become a long association with the provincial Department of Education, the chief controlling authority for the entire educational system. In 1933, the

psychological distance afforded by historical analysis. The second is that longitudinal meta-analyses can help to clarify whether and why certain problems appear to merit attention at specific times in history. Finally, they believe that historical perspectives on schooling can return us to the ideal that "public education has served - and still can serve - a common good.” Hansot and Tyack, "A Usable Past: Using History in Educational Policy," in Eighty-first Yearbook of the National Society for the Study of Education: Policy Making in Education (Chicago, Ill: National Society for the Study of Education, 1982), 21.

9 I am thankful to Barry and Lorna Lucas, Edith Lucas's nephew and his wife, for this information provided to me in an interview, June 21, 2004. They also provided family memoirs written by Edith's sister Evelyn.

10 The Camosun, 1919-1920, 26. Courtesy of the Victoria High School Archives.

11 "Personality of the Week: Dr. Edith E. Lucas," Colonist, 3 February, 1952, 16. Biographical details in the next paragraph are drawn from this source. 
department contracted with Lucas to write the province's first senior French-language correspondence courses. ${ }^{12}$ This was an important assignment insofar as the Correspondence Branch was the principal agency of government responsible for providing educational programs at a distance to youngsters thinly scattered across a province measuring almost one million square kilometers in size. ${ }^{13}$ Beginning in 1919, the province had decided to supply correspondence programs to families in settlements too small to furnish the ten school-age children necessary for the establishment of a school. Lucas's success as a course writer led to an invitation to join the province's educational service full-time in 1937 and, in 1941, she replaced the Correspondence Branch founder, John Gibson, as director of the high school branch. ${ }^{14}$ Within a year of assuming the directorship, Lucas found herself at the centre of a political tempest brought about by the internment and education of children of Japanese ancestry.

Long before the outbreak of World War II, British Columbia had been marked by anti-Japanese sentiments, which rose episodically as the economy declined, as immigration increased, and as hard-fought provincial elections drew near. ${ }^{15}$ After the bombing of Pearl Harbor in December 1941, and Canada's subsequent declaration of war against Japan, a wave of anti-Japanese hysteria swept the province. ${ }^{16}$ On February 24, 1942, in the wake of mounting public concern about treason and sabotage, the Dominion Government of Canada moved 100 men of Japanese ancestry from coastal areas to work camps in the province's interior. ${ }^{17}$ At that point, the Dominion government assigned the men "to work on completing the Jasper-Prince George Highway, a road considered vital to British Columbia's defense," ${ }^{18}$ but did not contemplate

12 Ibid. The high school correspondence branch had been established in 1929 with the purpose of reducing educational inequities that had plagued the geographically remote areas of the province since public education's inception in 1872.

13 Province of British Columbia, A Legacy for Learners: The Report of the Royal Commission on Education (Victoria: Queen's Printer, 1988), 26. See also F.H. Johnson, A History of Public Education in British Columbia (Vancouver: University of British Columbia, 1964), and T. Fleming, "The Imperial Age and After: Patterns of British Columbia School Leadership and the Institution of the Superintendency, 1849-1988,” BC Studies 81 (1989): 50-76. See also T. Fleming and T. Toutant, "“A Modern Box of Magic': School Radio in British Columbia, 1927-1984,” Journal of Distance Education (1994): 1-14.

14 “Dr. Edith Lucas Gets School Post,” Vancouver Sun, 20 Aug. 1941, 9.

15 See W.P. Ward, White Canada Forever, $2^{\text {nd }}$ ed. (Montreal: McGill-Queen's University Press, 1999), 128-29.

16 W.P. Ward, "British Columbia and the Japanese Evacuation," Canadian Historical Review 57 (1976): 298. See also P. Roy, "B.C.'s Fear of Asians," in A History of British Columbia - Selected Readings, ed. P. Roy (Toronto: Copp Clark Pitman, Ltd., 1989), 291.

17 "Plan to Move 100 More Japs Every 2 Days," Vancouver Daily Province, 24 Feb. 1942, 8.

18 “Advance Party of Japanese Leaves Vancouver for Jasper,” Vancouver Sun, 24 Feb. 1942, 17. 
relocating women or children. However, as fears about national security intensified, some 22,000 people of Japanese descent were moved from coastal communities over the next eleven months, including women and children.

Relocation was carried out under the auspices of the British Columbia Security Commission (BCSC), an agency established by the Dominion Government with powers to remove any residents of Japanese origin from their homes. The BCSC began its work by transporting Japanese evacuees from coastal points outside B.C.'s lower mainland to Hastings Exhibition Park in Vancouver before sending them to camps situated in abandoned mining towns and other isolated areas of the province's interior. ${ }^{19}$ Government authorities were also empowered to confiscate their property, to dispose of such property without consent or recompense, and to "repatriate" Japanese Canadians to Japan. Under this program, some 6,000 Japanese Canadians were eventually returned to Japan and thousands of others were scattered throughout Canada. Few remained in B.C. ${ }^{20}$

Among other things, the internment seriously compromised the education of children of Japanese ancestry. There were just over 5,000 Japanese-Canadian schoolchildren in British Columbia when the government announced the evacuation policy. They had earned reputations as intelligent, hardworking, and well-behaved, and of aboveaverage ability. ${ }^{21}$ Reports from schools indicated that Japanese-Canadian students were active in every aspect of school life and that they mixed well with other children. Teachers spoke fondly of them and, as antiJapanese sentiments increased in 1938, the B.C. Teachers' Federation defended them, condemning anti-Japanese attitudes as "dangerous and un-Christian."22

19 T. Berger, "The Banished Japanese Canadians," in Ethnic Canada, ed. Leo Driedger (Toronto: Copp Clark Pitman Ltd., 1987), 387. See also N. Kelly and M. Trebilcock, The Making of the Mosaic: A History of Canadian Immigration Policy (Toronto: University of Toronto Press, 1998), 294; "Entire Japanese Community Will Take Over Ghost Town,” Vancouver Daily Province, 12 June 1942, 5.

20 T. Takata, Nikkei Legacy: The Story of Japanese Canadians from Settlement to Today (Toronto: New Canada Publications, 1983), 141.

21 H.K. Hutchison, "Dimensions of Ethnic Education: The Japanese in British Columbia, 1880-1940" (MA thesis, University of Victoria, 1972). See also M. Ashworth, The Forces Which Shaped Them (Vancouver: New Star Books, 1979); J. Dahlie, "The Japanese in B.C.: Lost Opportunity? Some Aspects of the Education of Minorities,” BC Studies 8 (Winter 1970-71): 3-16; P. Roy, “'Due to Their Keenness': The Education of Japanese Canadian Children in the British Columbia Interior Housing Settlements During World War Two," in Children, Teachers and Schools in the History of British Columbia, ed. J. Barman, N. Sutherland, and J.D. Wilson (Calgary: Detselig, 1995), 375-92; P.L. Smith, Come Give a Cheer! One Hundred Years of Victoria High School, 1876-1976 (Vancouver: Evergreen Press, 1976), 103; "A Lesson in Brotherhood: Children of 31 Nations Mix Happily in Strathcona School,” Vancouver Daily Province, 22 Jan. 1940, 20. 22 “Isn’t It About Time That We Spoke Up?” Editorial, The B.C. Teacher 18 (Oct. 1938): 287. 
Teachers and administrators who worked closely with Japanese pupils also sought to protect their students' academic well being. In April 1942, A.R. MacNeill, the highly popular principal of Richmond High School, which had enrolled large numbers of Japanese students since its establishment, informed S.J. Willis, provincial Superintendent of Education, about his apprehension over the rumoured removal of the Japanese students. In particular, he sought clarification about what would happen to students who qualified for university entrance, and advocated free-of-charge correspondence courses for evacuated students so they could maintain their academic studies. ${ }^{23}$

Unfortunately, elected politicians were not as supportive as such educators. The provincial government felt that because the federal government had orchestrated the relocation, the province was no longer accountable for educating children of Japanese ancestry. ${ }^{24}$ This was partly because many interior schools did not have the physical capacity to accommodate the Japanese children, although small numbers of children were "squeezed in" where possible. ${ }^{25}$ One of the government's main concerns, however, appears to have been a lack of human and financial resources. Provincial education minister H.G. Perry estimated that the total cost of educating the roughly 5,000 interned school children would be $\$ 343,026$ - of which approximately $\$ 230,000$ would be needed to construct new buildings in the interior settlements with the rest going to "teachers' salaries, textbooks and incidental expenses.” Furthermore, Perry and his government argued that since the evacuees no longer paid property taxes, revenues could not be generated to cover the costs of their education. ${ }^{26}$

The educational problems generated by the war did not only affect the interned students. Throughout World War II, education in B.C. suffered from a lack of human as well as financial and material resources. In August 1942, the Vancouver Sun newspaper announced that the "harassed Department of Education" was making "desperate attempts to secure instruction” for children whose teachers had left teaching to

23 British Columbia Archives (BCA), GR1219, High School Correspondence, 19421951, File: Japanese, MacNeill to Willis.

24 K. Adachi, The Enemy That Never Was (Toronto: McClelland and Stewart Inc., 1991), 263-65; P. Roy, J.L. Granatstein, M. Iino, and H. Takamura, Mutual Hostages: Canadians and Japanese During the Second World War (Toronto: University of Toronto Press, 1990), 131; Roy, "Due to Their Keenness," 375; “Japanese Education Held Ottawa Charge,” Colonist, 20 Aug. 1942, 2; “Japanese Exodus Speeds Up to Meet Sept. 30 Deadline,” Vancouver Sun, 1 Sept. 1942, 13.

25 A. Glanville, Schools of the Boundary: 1891-1991 (Merritt, B.C.: Sonotek Publishing Ltd., 1991), 87. See also BCA, GR1219, Correspondence Courses, Willis to Tyrwhitt; "Special Grade Schools Planned for Jap Children at B.C. Points," Vancouver Daily Province, 15 June 1942, 5. A severe teacher shortage in B.C. due to the war also prevented the government from hiring extra Caucasian teachers in the interior settlements. See Roy, "Due to Their Keenness," 379.

26 “Japanese Education Held Ottawa Charge,” Colonist, 20 Aug. 1942, 2. 
support the war effort. Approximately 50 provincial schools were closed as the Department of Education "appealed for former teachers in British Columbia and elsewhere to help out." ${ }^{27}$ In addition, by refusing to permit B.C. teachers to instruct Japanese children removed to rural areas, the department hoped to "conserve teachers" for areas where greater numbers of students resided. ${ }^{28}$ To ensure equity throughout the province, the government encouraged students left without teachers to enroll in correspondence courses through the Department of Education's High School Correspondence Branch, which had significantly increased its production capacity to meet increased demand.

While government officials scrambled to deal with the wartime shortages, others stepped in to assist the evacuees. Roman Catholic, Anglican, and United Church groups offered to provide facilities for educating some of the evacuee children. ${ }^{29}$ According to Patricia Roy, it was "the civil servants in the BCSC [who] persuaded their political masters that educating children in the interior housing settlements was 'a matter of fairness to the future of the children' and 'in the national interest'.." ${ }^{\prime 30}$ As a result of this persuasion, on September 18th, 1942, the BCSC announced that it would cover the cost of elementary correspondence programs for interned pupils up to grade 8. Letters between Anna Miller, Director of Elementary Correspondence in the education department, and officials in the BCSC indicate that as early as July 1942 the branch provided marking support for lessons in elementary literature, language, health, social studies, grammar, and general science. ${ }^{31}$

Historical accounts of the internment show that "high school students - [unlike their primary counterparts] were [officially] left to fend for themselves through correspondence courses - at their own expense.”32 These historical accounts appear at odds with education department records involving Lucas. In April 1942, provincial school chief Willis informed Lucas that the BCSC was considering correspondence education for high school students. ${ }^{33}$ By June 15, 1942, plans were

27 "Government Widens Plan to Recruit More Teachers," Vancouver Sun, 28 Aug. 1942; “Japanese Education Held Ottawa Charge,” Colonist, 20 Aug. 1942, 2.

28 "Government Widens Plan to Recruit More Teachers,” Vancouver Sun, 28 Aug. 1942, 17.

29 Dahlie, “The Japanese in B.C.: Lost Opportunity?” 13; Glanville, Schools of the Boundary, 86-89.

30 See Roy, "Due to Their Keenness," 376.

31 BCA, GR1219, Correspondence Courses, Miller to McRae, 29 July 1942; Miller to Tyrwhitt, 6 Aug.1942; Miller to McRae, 6 Aug. 1942.

32 "Japs' Chances for Education Better Than B.C. Whites," Province, 22 May 1943, 8. See Adachi, The Enemy That Never Was, 263-64 and Ashworth, The Forces Which Shaped Them, 125. See also J.D. Wilson, "Review of The Forces Which Shaped Them: A History of the Education of Minority Group Children in British Columbia," BC Studies 46 (1980): 91-96.

33 BCA, GR1219, Correspondence Courses, Willis to Lucas, April 12, 1942. 
approved for correspondence courses to "be made available to high school students under supervisors, with regular hours of study. ${ }^{34}$ Under this arrangement, individual correspondence lessons were purchased and shared by several students working under the supervision of JapaneseCanadian adults. ${ }^{35}$

By February 1943, Lucas and Cleo Booth, who supervised the BCSC's education file, were corresponding at length regarding arrangements for end-of-year high school examinations. ${ }^{36}$ Moreover, in response to a request from internee supervisors, Lucas and her staff postponed end-of-year examinations from June to August to accommodate evacuees whose educational progress had been hampered by administrative "delays and other handicaps" brought about by the internment. $^{37}$

Lucas and her colleagues in the High School Correspondence Branch were not alone in their attempts to help evacuee children. Other educational administrators within and outside government also assisted in educating interned children. In a letter to the elementary correspondence head, Anna Miller, in October 1942, the BCSC indicated that 2,418 elementary school students had benefited from correspondence lessons at a total cost to the Commission of $\$ 3,344.45 .{ }^{38}$ Later that month, J.A. Tyrwhitt of the BCSC wrote to Miller indicating his need for approximately 1,020 copies of New Canadian Arithmetic (Books I and II), since the books were no longer prescribed by the provincial education department and, therefore, were unavailable from the Textbook Branch. ${ }^{39}$ Since correspondence lessons were based on the old texts, Miller appealed to the influential superintendent of the Vancouver Schools, H.N. MacCorkindale, to supply the Branch with surplus copies from the city system. ${ }^{40}$ Nine days later superintendent MacCorkindale provided Miller with 1,020 texts that she then dispatched to the BCSC. ${ }^{41}$ Further

34 "Special Grade Schools Planned for Jap Children at BC Points," Vancouver Daily Province, 15 June 1942, 5: "Will Educate the Japanese,” Colonist, 19 Sept. 1942, 1; “Japs' Chances for Education Better Than B.C. Whites,” Province, 22 May 1943, 8.

35 BCA, GR1219, Correspondence Courses, Lucas to Takimoto, 29 Sept. 1942. This "user pay" system was not unlike the experiences of many non-interned, geographically remote students who enrolled in and paid for their own high school correspondence courses. At the start of the war in 1939, the branch enrolled 3,101 such pupils. The total jumped to 3,982 in 1941 as branch staff scrambled to accommodate additional pupils whose schools were forced to close due to wartime teacher shortages. See Annual Report of the Public Schools of British Columbia, 1939-40 and 1940-41.

36 BCA, GR1219, Correspondence Courses, Booth to Lucas, 1 Feb. 1943. The file holds other, similar letters.

37 Ibid., Booth to Lucas, 26 April 1943; Lucas to Booth, 11 May 1943.

38 Ibid., Tyrwhitt to Miller, 22 Oct. 1942. Note that the BCSC provided the lessons to the teachers and not directly to individual students, who were not officially permitted to enroll.

39 Ibid., Tyrwhitt to Miller, 6 Oct. 1942.

40 Ibid., Miller to MacCorkindale, 6 Oct. 1942.

41 Ibid., MacCorkindale to Miller, 15 Oct. 1942. 
assistance was extended to the evacuees by Vancouver Normal School faculty who offered annual summer school courses from Vancouver to New Denver, a small community in the province's interior, to accommodate BCSC school instructors. ${ }^{42}$

All these events occurred despite the province's official position that government was not obliged to educate the evacuees nor permit them to enroll in correspondence courses. ${ }^{43}$ This meant, of course, that the Department of Education was caught in a dilemma, with educators such as Lucas, Miller, and MacCorkindale quietly working behind the scenes to assist evacuated youngsters wherever they could. Although the full extent of the work undertaken by these educators may never be known, a letter to Lucas from Harry Shibuya, the Japanese supervisor at Alpine Lodge in Cascade B.C., suggests that her assistance was greatly appreciated within the evacuee community. Shibuya claimed that Tyrwhitt of the Securities Commission had "acquainted" him with the efforts Lucas had "exerted on behalf of the Canadians of Japanese parentage, in the matter of their education." He closed the letter by extending his thanks for her "sense of justice and fair-play" which she showed on "behalf of the unfortunate children of evacuees." 44

These same qualities also served Lucas well after the war. As part of Canada's post-World War II settlement of "displaced persons," many non-English-speaking European women came to British Columbia in 1948 seeking work as domestics. The Young Women's Christian Association in Victoria (YWCA), where most resided, undertook, among other things, to give them classes in English. YWCA volunteer teachers were soon overwhelmed by the magnitude of this work and the insufficiency of resources, prompting the deputy minister of education to request that Lucas "take charge" of the English-language and citizenship program. ${ }^{45}$

Although Lucas, a seasoned teacher and principal, had never before prepared lessons for adult immigrants, she was cognizant that their needs differed from those of children and adolescents. Finding there was "no book on the market suitable for teaching English to intelligent adults," Lucas devised her own strategy." ${ }^{46}$ On her own time after work Lucas organized a class of newcomers to meet in the evenings in her Victoria office, a stone's throw from the YWCA's quarters. Once she had prepared and "field tested" a lesson with her own students, she had it

42 Roy, "Due to Their Keenness," 379.

43 BCA, GR1219, Willis to Tyrwhitt, 6 Oct. 1942; Miller to Tyrwhitt, 19 Oct. 1942; and Miller to Ovans, General Secretary of the B.C.T.F., 20 Feb. 1945.

44 Ibid., Shibuya to Lucas, 10 Nov. 1942.

45 “Book Enables 'New Canucks' To Outshine 'Old Canadians,'” Vancouver Sun, 7 Jan. 1956, 11.

46 Ibid. 
"mimeographed and sent to the YWCA classes for their guidance."47 Lucas eventually compiled her lessons into two books, entitled English I and English II, each totalling over 300 pages. Upon completing English II, students could sit an examination that entitled them to a "certificate in English and citizenship," a document they could present as evidence of readiness when applying for Canadian citizenship. By 1954, there were over 115 night schools in B.C. using Lucas's textbooks, which she described as "instruction in the rights and responsibilities of Canadian citizenship, teaching at the same time practical English and our customs." 48

In 1957, when the Canadian government agreed to take in Hungarian refugees following the failed 1956 anti-Communist revolution, the Vancouver School Board launched special ESL classes for Hungarian children, teens, and adults who were resettling in British Columbia. Although the Secretary of State's office in Ottawa furnished many materials for these classes, the B.C. Correspondence Branch under Lucas's direction also supplied some 1,200 courses of "English for New Canadians" and "Preparation for Citizenship" to Hungarian refugees. ${ }^{49}$ By 1960-61, even after the eastern European influx had begun to subside, the British Columbia Department of Education continued to fund 10 teachers working with 156 students in the Vancouver school district. ${ }^{50}$

As a member of the Canadian Citizenship Council and an immigrant to Canada herself, Lucas considered the development of English I and II to be a "labour of love," produced mostly during her own, unpaid time. Lucas preferred to produce her own materials from scratch since she disapproved of many of the available language texts, whose pages were rife with stilted, formulaic phrases such as "the pen of my aunt is under the lilac bush.” Lucas took pride in her works, which were well illustrated with phrases built around the daily needs of the adult immigrants "in the sort of sequence in which they are naturally spoken."51

Although first and foremost an educational civil servant, Lucas proved adept at marketing her books and the other resources produced by

47 Ibid. Each lesson consisted of formal grammar, vocabulary drill, and pages of reading material about a fictitious immigrant family experiencing various aspects of Canadian life, such as government, banking, property insurance, taxation, home decoration, and workmen's compensation.

48 "Personality of the Week: Dr. Edith E. Lucas,” Colonist, 3 Feb. 1952, 16.

49 In 1954 a Federal-Provincial Agreement formalized the provision of Secretary of State materials to provincial governments for citizenship instruction, aimed at "newcomers to Canada who were over school age." See Memorandum of J.R. Fleming, Superintendent, Financial Services, Department of Education, to the Secretary-Treasurers of all school districts, 9 April 1974. Attached to the memo is a copy of the FederalProvincial Agreement, dated 31 March 1954. BCA, Provincial Secretary, GR1661.

50 Vancouver Board of School Trustees, Annual Report, 1960-61, 2. After the early 1960s, the provincial education department's support for ESL classes was somewhat intermittent and inconsistent, mainly in response to districts' requests - in particular in Vancouver.

51 “Personality of the Week: Dr. Edith E. Lucas,” Colonist, 3 Feb. 1952, 16. 
the correspondence branch. With information provided to her by the federal Citizenship and Immigration branch, Lucas would write to Canadians sponsoring or employing recent immigrants, offering them her English-language materials. By the early 1950s, Lucas was receiving requests for her materials from public school teachers across Canada and as far away as California. In keeping with official custom of the time, Lucas replied personally to all requests, sending information and materials free of charge. ${ }^{52}$

During her time as a civil servant, Lucas's department handled over 100 different correspondence courses ranging from "mathematics and French to steam engineering and frame house construction." ${ }^{\text {"53 }}$ A 1941 survey of student enrolment revealed a highly varied student population, of which 27 per cent of the 3,900 enrolled were adults. Many of Lucas's enrollees were physically marginalized from mainstream society, including 273 who were confined to hospital beds, 104 B.C. Penitentiary inmates, and 20 inmates from Oakalla prison. A further 18 students were enrolled from the Girls' Industrial Home and 20 from New Haven, the boys' home. Many enrollees not only passed their senior matriculation but won scholarships as well as other honours. ${ }^{54}$ One such award went to Horst Kramer, a Rumanian immigrant, who won a major university entrance bursary for academic excellence in 1956. He had taken all of his high school education through correspondence, beginning with Lucas's English for New Canadians I and II. ${ }^{55}$

Lucas's correspondence branch had also helped many new settlers to endure the hardships experienced in some of Canada's most geographically remote areas. In 1941, only three non-native women lived in the Fort Selkirk district of the Yukon. They would meet on Thursdays to sew and knit for soldiers abroad. One of the three, Kathleen Cowaret, took up the study of French through Lucas's correspondence education school. Through Cowaret's “delightful, chatty letters,” Edith Lucas learned of the lonely life in the far north for women whose husbands were absent on trapping expeditions for lengthy periods of time. ${ }^{56}$ Over the years, appreciative parents informed Lucas that "without assurance of

52 BCA, GR1219, Couling to Lucas, 30 Oct. 1959; Anderson to Lucas, 22 March 1950; Lucas to Allyn, 3 April 1950.

53 "Personality of the Week: Dr. Edith E. Lucas," Colonist, 3 Feb. 1952, 16.

54 "Spirit of Yukon Maintains Wide Interest in World Affairs," Province, 13 Sept. $1941,14$.

55 “Book Enables 'New Canucks' To Outshine 'Old Canadians,'” Vancouver Sun, 7 Jan. 1956, 11. The B.C. Archives contains a full file of former students' letters wishing Lucas well on her retirement and thanking her for encouragement and support. One such student, Edwin Neave, who had graduated from the Correspondence school in 1952, went on to obtain a bachelor's degree and a Ph.D. in Business Administration from the University of British Columbia. B.C. Archives, MS-0844, Wells, Edith Ethel.

56 "Spirit of Yukon Maintains Wide Interest in World Affairs," Province, 13 Sept. 1941, 14. 
education for their children through correspondence, they never would have ventured into remote parts of B.C." 57

By the time Edith Lucas left the civil service in 1963, she had spent over twenty-five years building the reputation of B.C.'s High School Correspondence branch into "international prominence."58 The branch grew from serving 2,000 pupils in 1940 to 20,000 in $1963 .{ }^{59}$ Through her publications in scholarly journals and invited talks on topics such as correspondence schooling and adult education, Lucas extolled the virtues of correspondence education. ${ }^{60}$ At the 1959 annual convention of the B.C. School Trustees Association, Lucas lectured school board members that, in regular schools, "there is a tendency among students to expect the teacher to do all the work." ${ }^{1}$ In contrast, Lucas asserted that correspondence students "learn quickly to stand on their own feet," and in so doing, developed perseverance and willpower that helped them to excel at their studies. ${ }^{62}$ Not surprisingly, Lucas sought to foster in her students the discipline and resourcefulness that she had learned herself as an immigrant child, the qualities that had taken her from a working-class neighbourhood in Victoria to the classrooms of the Sorbonne, and the independent-mindedness that she had demonstrated throughout her career in government trying to surmount the geographic, racial, and ethnic inequalities that divided British Columbia's society as surely as its great mountain ranges.

In 1960, as testament to her international stature, the Ford Foundation selected her to set up a correspondence program for the West Indies. ${ }^{63}$ In 1963, Lucas decided to retire early for several reasons. Troubled throughout her life with a serious goiter, her physical energies had begun to wane. Moreover, the education department was on the verge of reorganization. Finally, she felt that after such reorganization, the branch should be in the hands of younger people. With her usual blend of humour and humility, she noted that she did not want to "crawl to the goal post." 64

Lucas's story provides contemporary researchers with a window into a forgotten world of educational government - a world controlled almost entirely by professionals inside a well-co-ordinated system in which the provincial government worked harmoniously with its department of education administrators, school and district teachers and administrators,

57 "B.C. Correspondence Course Students Soon Learn to Stand on Their Own Feet," Colonist, 22 Oct. 1959, 7.

58 "Lighting a Torch for Learning," Times, 25 Oct. 1963, 4.

59 “Dr. Edith Lucas Resigns From B.C. School by Mail,” Province, 23 Oct. 1963, 3.

60 BCA, GR1219, Lucas to Allyn, 3 April 1950; "Famous B.C. Educator Closing

Honored Career," Colonist, 23 Oct. 1963, 8.

61 "B.C. Correspondence Course Students Soon Learn to Stand on Their Own Feet," Colonist, 22 Oct. 1959, 7.

62 Ibid.

63 "Woman Educator Gets Assignment in West Indies,” Times, 7 Dec. 1960, 21.

64 "Famous B.C. Educator Closing Honored Career," Colonist, 23 Oct. 1963, 8. 
normal school personnel, the B.C. Teachers' Federation - and even the federal Citizenship and Immigration branch. Described in the U.S. by David Tyack and Elisabeth Hansot as "managers of virtue," the educational experts of the early-twentieth century ran a "closed system" of governance. ${ }^{65}$ From her position inside the education department, Lucas could, and did, bypass government's original policy to ignore the education of Japanese-Canadian internees. As a senior civil servant, she could, and did, make decisions that mattered to youngsters, as she did in postponing the 1943 year-end examinations. Likewise, with the help of Vancouver superintendent H.N. MacCorkindate, Anna Miller was able to provide interned children with 1,020 copies of New Canadian Arithmetic within nine short days. Vancouver Normal School staff stepped up to the challenge every summer in New Denver in order to provide BCSC school instructors with professional development. And finally, when Lucas was unable to find a suitable textbook from which to teach English to adult immigrants, she simply created her own.

But the tight control that individuals such as Lucas, MacCorkindale, Miller, and others exerted over British Columbia's public education system was coming to an end. The latitude and independence enjoyed by Lucas and her senior colleagues in the province's educational civil service during what Thomas Fleming has described as the "Imperial Age of School Administration" began dissolving in the late 1960s after a decade of social unrest and societal pressures for more democratic approaches to public policy. ${ }^{66} \mathrm{By}$ the end of the 1960s, "the old notion of the common school as a public good" had become "as antiquated as the one-room school." 67

Like much of the western world, British Columbia experienced a fundamental shift during the "equality revolution" that came to fruition during the late 1960s and early 1970s. At the heart of the social reforms, argues Jean Barman, were changing attitudes toward the place in society of traditionally marginalized groups: women, the union movement, and racial and ethnic minorities. ${ }^{68}$ Governments throughout North America were forced to enact reforms ensuring greater equality of access to secondary schooling during the early 1970s, an era in Canadian public policy-making that political scientist Ronald Manzer characterizes as

65 See D. Tyack and E. Hansot, Managers of Virtue: Public School Leadership in America, 1820-1980 (New York: Basic Books, 1982), 7.

66 See T. Fleming, "In the Imperial Age and After: Patterns of British Columbia School Leadership and the Institution of the Superintendency, 1849-1988,” BC Studies 81 (Spring 1989): 50-76, and Fleming, "From Educational Government to the Government of Education.”

67 Tyack and Hansot, Managers of Virtue, 7.

68 J. Barman, The West Beyond the West: A History of British Columbia, rev. ed. (Toronto: University of Toronto Press, 1995). 
"ethical liberalism.”" ${ }^{\circ 9}$ Prompted in large part by the American civil rights movement and student activism against the Vietnam War, "antiEstablishment" sentiments prompted educational reformers to seek innovative ways to "de-institutionalize" and decentralize schooling. ${ }^{70}$

In British Columbia, the intents of this reform came to fruition in 1972 with the election of Dave Barrett's left-wing New Democratic Party (NDP) and the appointment of a new education minister, Eileen Dailly. ${ }^{{ }_{1}}$ Dailly, a former teacher and school board trustee, concurred with the critics of education who had become more vociferous in claiming that B.C.'s school system was outmoded and needed to become more responsive to the needs of its students. In her 1975 address to the annual conference of the B.C. Teachers' Federation, she vowed that she had "no intention of swinging the pendulum back." ${ }^{72}$ Dailly declared that teachers, administrators, and government were "in the centre of the struggle for control of public education" and were "faced with the dilemma of maintaining a common public school system in a diverse, pluralistic society." ${ }^{\text {"73 }}$ Following the lead of the federal government of the day, she vowed to decentralize policy-making and refocus the system around the teacher, the parent, and the child instead of the teacher, the principal, and the superintendent.

\section{Mary Ashworth: Advocate from the Outside}

It is within this new context of provincial and local "power sharing" that the discussion turns to Mary Ashworth's career. Ashworth arrived in Canada in April 1949 following her service in the Women's Air Corps in Britain. She completed her normal school training in the early 1950s and taught elementary school in Vancouver from 1955 to 1967, at which time she enrolled at the University of British Columbia (UBC) to complete a Master's degree in language education. In 1972, she began to teach UBC's education course for pre-service teachers called "Teaching English as a Second Language.” Between 1972 and her retirement in 1988, Ashworth authored 11 books and over 90 articles, all the while battling the provincial government to extend and improve educational services to minority-language learners.

69 R. Manzer, Public Policies and Political Development in Canada (Toronto: University of Toronto Press, 1985), and R. Manzer, Public Schools and Political Ideas: Canadian Educational Policy in Historical Perspective (Toronto: University of Toronto Press, 1994).

70 G.L. Gutek, A History of the Western Educational Experience, 2d. ed. (Chicago, Ill: Waveland Press, Inc., 1995), 500-512.

71 T. Fleming, "From Educational Government to the Government of Education."

72 BCA, GR1561, Files of Andy Soles, B.C. Ministry of Education, an address by the Honourable Eileen Dailly, Minister of Education, to the B.C.T.F., Vancouver, B.C., 31 March 1975.

73 Ibid. 
The roots of Ashworth's work on behalf of minority learners originated in the years between Lucas's retirement from educational government in 1963 and Ashworth's appointment at UBC. Throughout the late 1960s, the demands for educational services for non-Englishspeaking children grew rapidly, due in part to increasing numbers of nonEnglish-speaking immigrants. ${ }^{74}$ But Lucas's retirement from the civil service and the move toward greater educational decentralization had created a void in government with no one officially designated to oversee minority education in the province. In 1967 UBC attempted to address the needs of provincial educators in this regard by inviting London University professor, Val Elliot, to offer a course on "Teaching English as a Second Language."

Since most of the province's new immigrants settled in and around Vancouver, the city school district engaged UBC's newly-trained Englishas-a-Second-Language teachers, adding four secondary and three elementary classes to the district's roster in 1968, for a total of 28 ESL classes. ${ }^{76}$ The number of ESL classes in Vancouver had expanded almost three-fold from 1961 to 1968 and, in 1969, the Vancouver School Board introduced a language assistance program at Britannia High School for non-English-speaking students, most of whom were Chinese. By the time Ashworth was appointed to teach UBC's ESL course in 1972, over 100 teachers were enrolled. ${ }^{77}$ That same year, B.C.'s provincial education department approved 52 "New Canadian" classes and, by 1975, more than tripled its ESL approvals to $189 .{ }^{78}$

Ashworth's strategy for improving the education of minority learners was two-fold. First, Ashworth worked within the UBC academic system to provide pre-service teachers with the knowledge and skills necessary to work with new Canadians. But she soon discovered that academic preparation was not sufficient. When the provincial government took up its crusade to decentralize policy-making and educational governance, Ashworth found herself in the awkward position of working with specialinterest groups to lobby the provincial government for better support for minority learners.

One such organization with which Ashworth worked was the Immigrant Services Society (ISS) of British Columbia, a non-profit organization staffed by volunteers to provide support for immigrants and refugees. Established in 1968 by federal member of parliament Harold Winch, the ISS offered English-language training, airport reception,

\footnotetext{
74 See Kelley and Trebilcock, The Making of the Mosaic.

75 Patricia Wakefield, "Pleez, I Wish to Speak Zee Eenglish,” B.C. Teacher 49 (Dec. 1969), 117.

76 Vancouver Board of School Trustees, Annual Report, 1967-68, 3.

77 F.H. Johnson, A History of Public Education in British Columbia, Amended Manuscript (Vancouver: University of British Columbia, 1965), 280.

78 M. Ashworth, "Immigrant Children and B.C. Schools," TESL TALK 9 (Winter 1978): 5 .
} 
transportation for immigrants and refugees, housing, financial aid, and food, as well as social events and bus tours. ${ }^{79}$ Although seemingly a "grassroots" community organization, the ISS was almost entirely supported by federal and provincial agencies. In 1974, for example, the ISS received $\$ 51,300$ in government operating grants: $\$ 33,800$ from federal Manpower and Immigration, \$7,500 from the Secretary of State, and $\$ 10,000$ from the B.C. Provincial Secretary. ${ }^{80}$ According to the society's 1974 accounts, only $\$ 343.49$ was collected in donations and $\$ 152.00$ received in membership dues. ${ }^{81}$ Between 1974 and 1977, the ISS forwarded eleven requests to B.C.'s provincial secretary for additional funding.

In June 1974, ISS vice-president Harold Winch requested additional money from provincial secretary Ernie Hall to expand services for mothers and children under the age of five, as well as for policy development and administrative support. ${ }^{82}$ On July 3, 1974, Laurie Wallace, Deputy Provincial Secretary, forwarded Winch's letter to John Meredith, Superintendent of Educational Programmes at the Department of Education and asked for "comments and recommendations as to the Department of Education, assuming responsibility for the on-going administration of this program of providing English-language training to immigrants in British Columbia." 83

Several days later, Meredith replied that the "Department of Education is assuming, or is under the impression that it is assuming, full responsibility for providing language training programs through colleges, schools and adult education authorities." Meredith apparently saw no reason for the society to provide services and grants to school boards and college councils for language training, since they could already obtain funds for this purpose from the Department of Education. He also advised that it was beyond the public schools' mandate to deal with prekindergarten children and recommended that Winch contact the provincial human resources department "since they are in the Day Care Centre business.” Despite his protestations, however, Meredith asked Wallace for more information in order to determine "whether or not there [was] need to or possibilities of expanding the educational services needed." 84

In response to Meredith's comments, Winch told Wallace that the "local level authorities are either ignorant of certain needs in the English

79 Winch had been MLA for Vancouver East from 1933 to 1953. He was also plagued by controversy for much of his career due to his support for the Japanese internment. Immigrant Services Society website: see

http:// www.candianenterprises.org/immigrantservicessocietyofbc/index.htm

80 BCA, MS1163, Box 13: Provincial Secretary, Grant Files: 1956-1978.

81 Ibid., Provincial Secretary, File: The Vancouver Immigrant Services Society: Statement of Revenue and Expenditure, Year ended March 31, 1974.

82 Ibid., Provincial Secretary, Grant Files, Harold Winch to Ernest Hall, 26 June 1974.

83 Ibid., Provincial Secretary, Laurie Wallace to John Meredith, 3 July 1974.

84 Ibid., Provincial Secretary, Meredith to Wallace, 10 July 1974. 
Language Training field" or were "unwilling to take advantage of resources provided under the responsibility of the Department of Education., ${ }^{, 85}$ Winch challenged Meredith's claim that pre-kindergarten services were beyond the mandate of the education department by stating it was "a matter of education, not day care," and expressed a desire "to enlarge on this aspect of the matter." In response, Meredith arranged a meeting between the education department and the ISS where the issues were discussed and where Meredith reiterated the department's stance. Meredith also informed the ISS that the Vancouver School Board had changed its ESL policy and now provided specialized language instruction for children under the age of nine. This, Meredith concluded, "should result in Boards and College Councils being able to respond more extensively to demands for language training classes." ${ }^{\text {"D6 Discussion }}$ between the ISS and the Department over the matter thereafter ceased.

By the mid-1970s, Canada's economic outlook - like that of the United States - was grim. Skyrocketing inflation and slowing economic activity led to more restricted budgets and more restrained and pessimistic outlooks about education. A fiscally anxious public began to demand more rigorous education standards and a return to the basics of schooling. ${ }^{87}$ In this continent-wide economic climate, B.C.'s 1976 provincial election saw the defeat of the left-leaning New Democratic Party and the re-election of B.C.'s right-of-centre Social Credit party, which resulted in the appointment of Patrick McGeer, a former medical doctor and independent schools advocate, as education minister. In spite of prevailing government sentiments about the prudence of fiscal restraint, McGeer's executive assistant, James Bennett, was highly supportive of grassroots lobby groups. In particular, he sought to increase government's support of one such group, the Canadian Council for Christians and Jews (CCCJ). ${ }^{88}$

85 Ibid., Provincial Secretary, Winch to Wallace, 19 July 1974.

86 Ibid., Provincial Secretary, Grant Files, Meredith to Wallace, 19 Sept. 1974.

87 In the U.S. - largely as a result of the Vietnam War - mounting inflation, recession and expanding deficits triggered a change in the public mood and greatly hampered the funding of public education. According to Gerald Gutek, the "expansive" post-World War II decades were over, and in their place appeared such "key words" as "down sizing” and “retrenchment.” See G. Gutek, A History of the Western Educational Experience, $2{ }^{\text {nd }}$ ed. (Chicago: Waveland Press, 1995), 515.

88 The Council was first established in Toronto in 1947 by Rabbi Feinberg of the Holy Blossom Temple, Reverend David McClennan of Timothy Eaton United Church, and Father Nunan of the Jesuit Order as well as several lay persons. Spurred by gross human rights violations during World War II, these individuals wished to "promote justice, amity, understanding and co-operation among Protestants, Catholics and Jews" with a view to establishing "a social order in which the religious ideals of brotherhood and justice should become the standards of human relationship." Two of the council's programs were based in B.C.: Camp Brotherhood, a summer camp for 15 to 20 year olds and the International Student Exchange for 18 to 21 year olds. BCA, MS1163, Provincial Secretary, Box 24, Files of the CCCJ, A Short History of the Canadian Council of Christians and Jews in Canada, reprinted December 1972, by the Pacific Region CCCJ. 
Initially, the CCCJ's correspondence with the provincial government consisted purely of information and advertising. ${ }^{89}$ As early as 1970, however, the council had received a $\$ 2,500$ grant from the provincial secretary. ${ }^{90}$ As well, an increasing number of provincial politicians several of whom were in receipt of CCCJ correspondence through their legislative offices - came to sit on its national and regional boards of directors or on committees. ${ }^{91}$ Enlisting the support of politicians reflected the CCCJ's belief that by attracting the "top ten percent of the population" good results "would trickle down" throughout the rest of Canadian society. ${ }^{92}$

Beginning in March 1976, Charles Paris, Executive Director of the Pacific Region CCCJ, began corresponding with Bennett to discuss the services provided by the CCCJ. ${ }^{93}$ Soon after, Bennett contacted Joe Phillipson, Associate Deputy Minister of Education, requesting \$25,000 to help Paris and his resource team to continue delivering workshops on immigrant settlement around the lower mainland. ${ }^{94}$ Phillipson responded by contacting Vancouver superintendent Dante Lupini, and inquiring about the Vancouver board's satisfaction with Paris's work. While waiting for a reply from Phillipson, Bennett took the initiative and wrote to Paris for information regarding the possibility of establishing an advisory committee of government departments to deal with the "repercussion of Federal Immigration policies in B.C.”95 Bennett also sought \$20,000 in funding for Paris from Human Resources Minister Grace McCarthy, advising her that an immigration advisory committee would receive the Education Minister's support, in light of the alleged enormity of the immigration "problem" in Vancouver. ${ }^{96}$

Lupini replied to Phillipson that the "Vancouver School Board (VSB) [was] in concurrence with [Paris's] efforts” and that the district's assistant

89 Ibid., Provincial Secretary, Box 24, Files of the CCCJ, Smithson, Executive Director of the CCCJ, to W.A.C. Bennett, Premier of British Columbia, 25 Nov. 1969. 90 Ibid., Provincial Secretary, Box 24, Files of the CCCJ, Wallace to Smithson, 14 May 1970.

91 Ibid., Provincial Secretary, Box 24, CCCJ, Smithson to Mayor Frances H. Elford, M.B. Couvelier, and P.D. Pemberton Holmes, 15 March 1972. Listed among the directors for the Pacific Region CCCJ was Wade Stoneman, president of the ISS and UBC professor Joseph Katz (later appointed to the B.C. Human Rights Commission). See also BCA, G81-056, Minister of Education, 1975-1979: CCCJ, Charles B. Paris, Pacific Region CCCJ to James S. Bennett, Executive Assistant to McGeer, Minister of Education, 5 Aug. 1976.

92 BCA, GR81-056, Minister of Education, 1975-1979, CCCJ, Canadian Council of Christians and Jews, A Short History, Dec. 1972, 4.

93 Ibid., CCCJ, Charles Paris to James Bennett, 19 March 1976, and Paris to Bennett, June 23, 1976. In July 1976, the CCCJ's first president, Reverend Richard Jones, expressed his great pleasure to B.C. Premier Bill Bennett when the "Council involved thirteen students whose parents work[ed] with [the B.C.] government in exchange for visits with Quebec students.”

94 Ibid., CCCJ, Bennett to Joseph Phillipson, 20 July 1976.

95 Ibid., CCCJ, Paris to Bennett, 5 Aug. 1976.

96 Ibid., Immigration, Bennett to McCarthy, 9 Aug. 1976. 
superintendent Alf Clinton "was working closely with Paris."97 Lupini also informed Phillipson of Paris's multicultural resource team, jointly sponsored by the CCCJ and the ISS. Among the seven members of the team's Advisory Board were UBC's Mary Ashworth, Alf Clinton of the VSB, and Wade Stoneman of the ISS. Lupini advised that additional funding for the resource team had been acquired through the federal Manpower and Immigration Department, the Secretary of State, the Department of Education, and the Social Planning Department of the City of Vancouver.

On September 29, 1976, Phillipson informed Bennett that Paris's proposal for in-service training was a "laudable one and deserving of every assistance we can give" and he promised to seek sources for more funding. ${ }^{98}$ However, in the meantime, McCarthy informed McGeer that Paris should not receive additional funding since the CCCJ was already receiving \$3,500 in funding from her human resources ministry, which was also funding the ISS to a total of $\$ 72,000 .^{99}$ On March 15, 1977, Deputy Minister Walter Hardwick informed Lupini that the education department, now elevated to the status of a ministry, would not extend any more funding to the VSB for Paris's services. ${ }^{100}$ In the end, Hardwick's views won out over Bennett's and the CCCJ thereupon ceased requests for funding ESL and citizenship workshops.

Along with the ISS and the CCCJ, Ashworth worked closely with the Vancouver School Board, one of the most vocal advocates for increased services for immigrant children. Vancouver was also one of B.C.'s first districts to take advantage of Ottawa's "language training" funds offered by manpower and immigration. In 1971, the Vancouver school trustees noted a "high proportion of East Indian children" in schools close to the Sikh Temple in South Vancouver. ${ }^{101}$ Using federal "Opportunity for Youth” funds, the VSB launched a summer program to improve the children's English skills, to help their parents become familiar with the city, and to encourage the immigrants to socialize with Canadian children. The reality, however, was somewhat different. Although 14 per cent of the children at Sir Walter Moberly School were reportedly of East Indian descent, "forty percent had been born in Canada." A further 38 per cent of the students attending the program were of Japanese, Chinese, Greek, and Portuguese descent, of whom some were also likely born in Canada. The program's perceived success led to its continuation the following year under the VSB's full control. Nevertheless, during the second year the teacher had to leave the program for personal reasons. According to Ashworth, "with discrimination against East Indians on the increase the wisdom of segregating these children from the Caucasian

97 Ibid., CCCJ, Lupini to Phillipson, 13 Sept. 1976.

98 Ibid., CCCJ, Phillipson, 29 Sept. 1976.

99 Ibid., CCCJ, McCarthy to McGeer, 1 Sept. 1976.

100 Ibid., CCCJ, Walter Hardwick to Dante Lupini, 15 March 1977.

101 Ashworth, The Forces Which Shaped Them, 190. 
children was questioned and the class was in time disbanded and no final report issued." 102

In 1976, with inflation and unemployment on the rise, the Canadian public began to voice opposition to steadily rising federal immigration quotas. In an attempt to placate the electorate the federal government solicited public input on a draft "Green Paper" on immigration. Working closely with the VSB, the ISS and the CCCJ in December 1976, Ashworth drafted a response to the "Green Paper" and proposed a policy for immigrant settlement. In her proposal Ashworth claimed that government's failure "to provide adequate social and educational services to immigrants would be unwise and might even end up costing the taxpayer more dollars in the long run when remedial and emergency services [would] have to be reinstated." 103 Ashworth further asserted that if the mother of an immigrant child "is not learning English, her ignorance of the language may slow down the learning process of her children and in time isolate her from her family causing tensions which can ultimately break up the family.” Apart from its lack of supporting research, Ashworth's report was questionable in its claims. For example, Ashworth asserted that immigrants were "not accustomed to obtaining services from government institutions" and that "welfare” was dispensed in Asian societies by the extended family rather than by government agencies. Yet, later in the report, Ashworth reported that immigrants needed "expert counseling to help them solve their economic and personal problems. Private agencies," she claimed, were "of particular value in this field because of their great sensitivity to local community needs." ${ }^{104}$ Although private in name, the ISS was largely an arm of government and thus, in essence, a "government institution" from which, as Ashworth claimed, immigrants were "not accustomed to obtaining services."

In 1977, Vancouver witnessed the birth of another lobby group with whom Mary Ashworth worked closely: "Directions ESL." It held two symposia on immigrant settlement in B.C. - one on January 22 and the other on April 23, both sponsored by other "grassroots" immigrant organizations: Britannia Community Services, the ISS, and the United Chinese Community Enrichment Society. ${ }^{105}$ Registered participants, resource people, and invited guests included UBC's Stoneman, UBC education professor and Vancouver Multicultural Society member Joseph Katz, VSB trustee Margaret Andrews, VSB's Dante Lupini, and

102 Ibid., 193.

103 BCA, G81-056, Minister of Education, 1975-1979, CCCJ, M. Ashworth, The Settlement of Immigrants: The Need for a Policy, Dec. 1976, 4.

104 Ibid.

105 BCA, Add. MSS 1163, Files of Scott Wallace, Box 5: Immigration. Also, Directions ESL, Report on the Symposium Held Saturday, 22 Jan. 1977; Directions ESL, Defining and Resolving the Problems in B.C., Report on the Second Symposium held Saturday, April 23, 1977: from the personal files of Naomi Katz, past president of Directions ESL. 
Katharine Mirhady, of the B.C. School Trustees' Association (BCSTA) - amongst others. Agendas for both symposia included guest plenary speakers, working groups to address aspects of immigration felt by the delegates to be particularly pressing, and recommendations for government action.

Soon after, Directions ESL president Naomi Katz sent reports from the symposia to education minister McGeer with twelve recommendations regarding public school kindergarten to grade 12 ESL instruction. ${ }^{106}$ Among these were recommendations for greater funding from provincial and federal governments; more in-service training for regular classroom teachers in the areas of language acquisition, cultural differences, and ESL methods; an ESL policy; ESL training for all teachers-in-training; funding for ethnic school-community liaison workers; and the use of volunteers in ESL settings. However, education minister McGeer deftly evaded the recommendations by insisting that the education ministry was pursuing a policy of decentralization and thus was vesting more power in school districts to deal with local matters. Undeterred, the lobby group once again requested from McGeer that a provincial co-ordinator be designated for ESL and that the province's mandate be enlarged to include more extensive ESL training for teachers working with immigrant children. ${ }^{107}$

Katz's correspondence to McGeer included two briefs presented to the province's Joint Board of Teacher Education on December 12, 1977. Both briefs included unsubstantiated assertions, including the claim that efficient content area teaching required teachers to gain "some understanding of how language is acquired and how it affects learning." ${ }^{108}$ One brief also asserted that language was "central to one's self identity and self-concept" since it "embodie[d] deeply held values and concepts." The brief added that the "transfer into a second language in a new environment is fraught with possibilities for psychological damage and social disorientation which could affect subsequent learning."

Provincial education authorities ignored these requests, arguing once again that it was not within their mandate to deal with such matters. The provincial position, however, was equivocal. On some occasions, the authorities claimed to be divesting more power to school districts to deal with local matters. On others, they argued that immigration matters fell under federal jurisdiction and therefore it was the federal government's

106 BCA, G81-056, Minister of Education, 1975-1979, ESL, N. Katz to Pat McGeer, 10 Jan.1978.

107 Ibid., Directions ESL, Katz to McGeer, 15 Feb. 1978.

108 Ibid., ESL, Standing Committee for Directions ESL, Briefs to the Joint Board of Teacher Education, 12 Dec. 1977.

109 Ibid. 
responsibility to "pay the cost of settling immigrants." ${ }^{110}$ Not surprisingly, federal officials denied this claim by pointing out that under the Canadian constitution, educational provision was a provincial matter. As both levels of government played cat-and-mouse over the scope of provincial and federal responsibilities, each continued sporadic support of the various agencies that had proliferated throughout the province under the auspices of improving services to minority learners.

WHAT CAN WE LEARN from the experiences of Edith Lucas and Mary Ashworth? Their lives were similar in several important ways. First, both Lucas and Ashworth were immigrants to Canada, from Ireland and England respectively. Second, they were both teachers who devoted much of their lives to promoting the education of minorities in British Columbia. Both women contributed greatly to ESL instruction, with Lucas producing practical resource materials for teachers working in public schools and with Ashworth preparing future ESL teachers and lobbying the provincial government to improve educational services for immigrant children.

Lastly, Lucas and Ashworth were both women and a tale of two women would be incomplete without at least a cursory discussion about the possible role that gender may have played in their professional lives. ${ }^{111}$ Edith Lucas was one of a handful of women to enter the ranks of the civil service in the early twentieth century - the first being Jessie McLenaghen in 1926. ${ }^{112}$ As noted by David Tyack and Elisabeth Hansot, in the first two decades of the twentieth century, "powerful movements were gaining momentum among women teachers," who protested the "domination of top administration and professional associations by males." ${ }^{113}$ Running parallel to the continent-wide suffrage movement of the time that sought to increase women's political, social, and economic equality, women teachers began winning an increasing percentage of supervisory and administrative positions in education. ${ }^{114}$ Indeed, in 1941, when Lucas assumed the directorship of the High School Correspondence

110 M. Ashworth, Blessed with Bilingual Brains: Education of Immigrant Children with English as a Second Language (Vancouver: Pacific Educational Press, 1988), 26.

111 The data sources considered for this research article lend themselves more appropriately to an analytic framework that deals with shifting policy perspectives. Therefore, this brief discussion on the role of gender is not intended to be exhaustive, but rather supplementary. Indeed, historical accounts of gender and education in British Columbia are stories that remain largely unwritten and are ripe for future research inquiry.

112 See L. Peterat and M.L. DeZwart, An Education for Women: The Founding of Home Economics Education in Canadian Public Schools (Charlottetown, PEI: Home Economics Collective, 1995), 77.

113 Tyack and Hansot, Managers of Virtue, 180-81.

114 Ibid. See also C. Shakeshaft, Women in Educational Administration (Newbury Park, CA: Sage, 1989). Shakeshaft notes that in 1928, for example, over half of all U.S. principals (in both elementary and secondary schools) were women. 
Branch, women accounted for 42 per cent of directors' positions in the provincial education department. ${ }^{115}$ However, these early-twentiethcentury gains were short-lived. ${ }^{116}$

By the time Mary Ashworth began her career as a professor at the University of British Columbia, only 13 per cent of Canadian college and university faculty were women, despite the fact that they constituted over 60 per cent of all elementary and secondary teachers in the country. ${ }^{117}$ Within the British Columbia civil service, women had slipped from holding 42 per cent of the directorship positions in 1941 to only 23 per cent in 1972. ${ }^{118}$ Although the total number of directorship positions grew three-fold in the ministry from 1972 to 1977 (from 13 to 39), the number of positions held by women declined to just one - or, just under 2 per cent. These data bear testimony to a far chillier climate for women in education during Mary Ashworth's career than during the professional life of Edith Lucas. Although it is beyond the scope of this paper to account fully for this transition to a chillier climate by the 1970s, these data beg for further research inquiry. ${ }^{119}$

In spite of their apparent similarities, Lucas and Ashworth were born almost a generation apart and their professional lives were shaped by other social and educational circumstances besides the changing role of women in education. Lucas began teaching in 1925 and obtained a doctorate from the Sorbonne in the 1930s, at a time when few Canadian women aspired to such educational achievements. She joined the provincial education department in 1937 and became director of the government's correspondence branch in 1941. Her contributions to minority education occurred during an era referred to by Fleming as the "liberal age" of schooling and by Manzer as the era of "economic liberalism.” During this era in educational history, which culminated in the early 1970s, historians tend to agree that elected politicians were generally content to leave educational matters to the educational civil service. ${ }^{120}$ To illustrate: when the deputy education minister asked Lucas in 1948 to "take charge" of the English and citizenship program, she organized a class of newcomers to meet in her office so that she could

115 Tabulations of the numbers of male and female directors are derived from the Annual Report of the Public Schools of British Columbia, 1940-41.

116 Tyack and Hansot, Managers of Virtue, 190.

117 S. Shack, The Two-Thirds Majority: Women in Canadian Education (Toronto: The Governing Council of the University of Toronto, 1973), 11.

118 Statistics tabulated from the Annual Report of the Public Schools of British Columbia, 1972-1973.

119 Mona Gleason has recently explored Canada’s post-World War II family life and the dilemma of "re-employing" returning servicemen. It is worth exploring further whether the post-war social discourse that encouraged women to vacate their jobs and to "embrace full-time domesticity and motherhood" is connected to the decline of women in senior educational posts. See Mona Gleason, Normalizing the Ideal: Psychology, Schooling, and the Family in Postwar Canada (Toronto: University of Toronto Press, 1999).

120 Fleming, “From Educational Government to the Government of Education,” 211. 
field-test her own materials and teaching approaches before disseminating them to other educators. Throughout her career she corresponded directly, and personally, with teachers, children, and their families throughout the province. In short, Lucas undertook her work in an era of clearly circumscribed liberalism. To use the words of liberal humanist Carl Rogers, Lucas moved "voluntarily, freely, responsibly, to play her significant part in a world whose determined events move[d] through her and through her spontaneous choice and will."121 Or, put another way, Lucas embodied liberalism's tenets that held that state-controlled education systems were to disseminate "faith in the autonomous individual, a secular government and a single language - all acting to unify citizens" throughout the polity. ${ }^{122}$

Conversely, Ashworth began her teaching career in the 1950s and her greatest impact on the lives of minority learners occurred after the rights revolution during a time in the 1970s referred to by Fleming as the "postliberal” era of schooling and by Manzer as "ethical liberalism.” Because of increasing sentiments favouring decentralization that resulted from this revolution, Ashworth's time was divided between her position as university educator on the one hand and her role as political advocate on the other, lobbying government for adequate human and material resources to educate minority learners.

Ashworth's life experiences differed significantly from Lucas's in another way as well. Whereas Lucas operated within the clearly delineated tenets of liberal ideology, the framework that circumscribed Ashworth's professional life was far less clear. While several government departments, such as the human resources ministry and the provincial secretary's office, supported grassroots lobby efforts, other government ministries, such as the provincial education ministry and the federal immigration department, maintained the discretion to refuse such requests, which they did on many occasions. Again to illustrate: John Meredith, Superintendent of Educational Programmes, turned down Harold Winch's 1974 request for additional funding for the ISS preschool program. In 1976, the federal immigration department failed to respond to Ashworth's draft immigrant settlement proposal, submitted in response to the "Green Paper" on immigration. In 1977, deputy education minister Walter Hardwick eventually vetoed Charles Paris's request to fund the CCCJ's immigrant settlement activities. That same year, provincial education minister McGeer denied requests from Directions ESL, arguing that it was not within the education ministry's mandate to deal with such issues as immigrants' psychological well-being. All the while, the federal government continually refused to earmark specific funds for teaching English to immigrant children, claiming that such an initiative would

121 C. Rogers, The Freedom to Learn for the 80's (Columbus, Ohio: Charles E. Merrill Publishing Co., 1983), 276.

122 Fuller, “Education Policy Under Cultural Pluralism,” 19. 
encroach on the constitutionally conferred right of Canadian provinces to deal with education.

What can explain government's inconsistent responses to these grassroots organizations? According to Fleming, the ministry's rhetoric of shared responsibility may have been nothing more than a "social and political lubricant to 'cool out' dissent, through what organizationalists term 'co-optation.","123 That is, ministry of education officials seemed willing to "talk the talk" of decentralization, as long as they were not forced to "walk the walk." As noted earlier in this paper, the old guard that had run the education department during Lucas's days were predominantly small "l" social liberals, motivated by progressive ideas about social and educational change and the value of rational thought over more traditional forms of cultural authority. Unhampered by more fiscally driven political concerns that marked the 1970s and after, Lucas manoeuvred freely throughout a world that extended beyond the formal kindergarten-to-grade twelve system, putting her in touch with such marginalized peoples as the Japanese internees, the domestics at the YWCA, prisoners in British Columbia's jails, women in northern trapping communities of the province, as well as students and teachers from as far afield as California who were interested in minority education. But by the early 1970s, the professional latitude enjoyed by Lucas and her colleagues had vanished, with elected officials assuming more and more power over the educational ship of state.

With government spending spiralling out of control by the 1970s, criticism from fiscally conservative constituents prompted elected politicians (such as McGeer) and political appointees (such as Hardwick) to confine public education's mandate to youngsters within the K-12 system. Although government claimed to be decentralizing control of public education, in reality, key decisions on how to allocate scarce resources merely shifted from the hands of civil servants and other professionals within the system to elected politicians and their political appointees, who weighed educational need against political consequences. These fiscally conscious officials strongly resisted lobby groups' entreaties to provide language and counselling services to preschoolers and their families, arguing that it was beyond the education system's mandate to provide daycare or other social welfare services. However, as control shifted from experts inside the education system to politicians outside the system, the ministry found itself having to reconcile its earlier "liberal model of public provision with an emerging neo-conservative or post-liberal view which favoured a more restrained approach to government's role in public and private life."124

123 Fleming, "From Educational Government to the Government of Education," 226-27. For the next two paragraphs, see ibid, 225-27.

124 Ibid., 225. 
Nevertheless, the ministry's strategy of paying lip-service to "powersharing" while at the same time practising restraint and tight fiscal control backfired in two ways. First, school trustees, the teachers' federation, university professors, and district staffs had all been educated in an earlier era when the education system had served a much broader social role and they continued to make demands on the system to support a broader mandate. Second, the rhetoric of "shared responsibility" inflated the expectations of these groups for greater control over the province's educational affairs. Soon, the question on everyone's mind was who, truly, was at the helm of the educational ship of state? ${ }^{125}$ This confused situation further weakened the ministry's legitimacy as educational guardian and, in the long run, fuelled the divisive and bitter power conflicts that erupted in British Columbia by the early 1980s, conflicts that still plague policy-makers who, in Fuller's words, are "torn between embracing Max Weber and engineering a tighter, mechanical system, or going with Adam Smith and blowing up the bureaucratic state." ${ }^{26}$

125 T. Fleming, "Canadian School Policy in Liberal and Post-Liberal Eras: Historical Perspectives on the Changing Social Context of Schooling, 1846-1990," Journal of Education Policy 6 (1991): 183-99; see also Tyack and Hansot, Managers of Virtue.

126 Fuller, "Education Policy Under Cultural Pluralism," 15. See also Fleming, "From Educational Government to the Government of Education," and Fleming, "Canadian School Policy in Liberal and Post-Liberal Eras.” 